\title{
Intestinal parasites in Meche community in relation to their socio-economic status
}

Nirmala Dhakal ${ }^{1}$ and Janak Raj Subedi ${ }^{2}$

${ }^{1}$ Former M.Sc. student, Central Department of Zoology, Tribhuvan University, Kirtipur, Nepal

${ }^{2}$ Lecturer, Central Department of Zoology, Tribhuvan University, Kirtipur, Nepal

\begin{abstract}
Background and Objectives: Intestinal parasites still establishes one of the important causes of public health problem in world, especially in developing countries like Nepal. The aim of the study is to determine the prevalence of intestinal parasites in Meche community of Jalthal Village Development Committee of Jhapa district in relation to their socio-economic status.
\end{abstract}

Material and Methods: Study was carried out during June to July 2017 in Meche community of Jalthal Village Development Committee of Jhapa district. A total of 150 human stool samples were randomly collected and examined using direct smear and concentration methods (sedimentation and flotation technique).

Results: Among total samples the prevalence of intestinal parasites in Meche community was $27.33 \%$. Prevalence rate in females were higher $32.47 \%$ than in males $21.91 \%$. There was no significant difference in the distribution of parasites between male and female $\left(\chi^{2}=1.6022, \mathrm{df}=1, \mathrm{p}\right.$ value $=0.2056$ ). The prevalence of the parasites was maximum in the age group 21- 40 years (47.22\%). Altogether 5 species of the intestinal parasites were detected. Among them Ascaris lumbricoides (19.33\%) topped the list followed by Taenia solium (2.67\%), Hookworm (2.67\%), Entamoeba coli (2.67\%) and Trichuris trichiura (2\%).

Conclusion: The high prevalence of infection in community seems directly related to unhygienic living condition, unsafe drinking water, unhygienic food, lack of health education, poor sanitary condition and low socio-economic status help to increase the burden of the infection in the community.

Key Words: Intestinal parasites, Infection, Meche people, socio-economic status

\section{INTRODUCTION}

Intestinal parasites are cosmopolitan in distribution. Intestinal parasitosis still establishes one of the important causes of public health problem in world, especially in developing countries like Nepal. Around 3.5 billion people globally are estimated to be affected by intestinal parasitosis and 450 million are sick as a result of these infections, the majority being children [1]. Intestinal parasitic disease is one of the global health burdens in many developing countries mainly due to fecal contamination of water, lack of adequate basic sanitation and environmental and socio-cultural factors enhancing parasitic transmission [2, 3]. More than one billion people are estimated to chronically infected 
with intestinal helminthes[4]. Among the intestinal parasitic infections, ascariasis, hookworm infection and trichuriasisare reported as the most common infection in the world, being responsible for considerable morbidity and mortality. Besides of causing morbidity and mortality, intestinal parasitic infections have been associated with physical weakness and low educational performance of the poor segments of the populations and intimately linked with low economic status, poor personal and environmental hygiene, tropical climate and low altitude[5].

Nepal is small and impoverished country situated in the south Asia, with infectious disease, including intestinal parasitosis, with high prevalence rate[6]. Particularly in rural area of Nepal, open air defecations are common that enhance the parasites to invade into individual. In Nepal, over 70\% morbidity and mortality rate concern with intestinal parasitic infection and is also reflected in "top ten disease of Nepal"[7]. Ascaris has remained as a leading human parasite in Nepal[8]. Diarrhea is caused by variety of etiological agents but of them intestinal parasitic infection alone contributes to a great extent in the cause of diarrhea and is one of the most common public health problems in Nepal[9].

It is reported that the prevalence of the intestinal parasites in Nepal varies considerably from one study to another study and reaches nearly $100 \%$ in some tropical areas.[10,11] In Nepal, children are more commonly infected than adults.[11,12] The intestinal helminth commonly reported from Nepalese children are Ascaris lumbricoides, hookworm and Trichuris trichiura.[13] The agents spread faeco-orally through contaminated sources.

\section{MATERIAL AND METHODS}

The study was conducted in JalthalVDC which lies in Jhapa district. Jhapa district is situated in terai region of eastern belt of Nepal. Jalthal is located in the southern part of the Jhapa district extending from Mahespur VDC in the east to Rajgadh VDC to the west with the location $267^{\prime} 01.24^{\prime \prime} \mathrm{N}$ and $87^{\circ} 5627.62^{\prime \prime} \mathrm{E}$ to $26^{\circ} 31^{\prime} 33.14^{\prime} \mathrm{N}$ and $88^{\circ} 0257.37 \mathrm{E}$. The study population comprised of Meche people residing in the Jalthal VDC of Jhapadistrict which is least developed rural area. The total population of Meche in national context is 4,380 , of which 4,076 reside in Jhapa district[14]. Jalthal VDC includes 9 wards in which 3, 4, 5,6,7,8 and 9 wards are inhabited by Meche people. Out of 13,363 population of Jalthal VDC, 10 and 11 are Meche people[15]. Mecheare mainly called Bodo, who mainly inhabit in Jalthal and Dhaijan VDCs of Jhapa [16]. The main occupation of the Meche people is agriculture and alcohol making by traditional method.

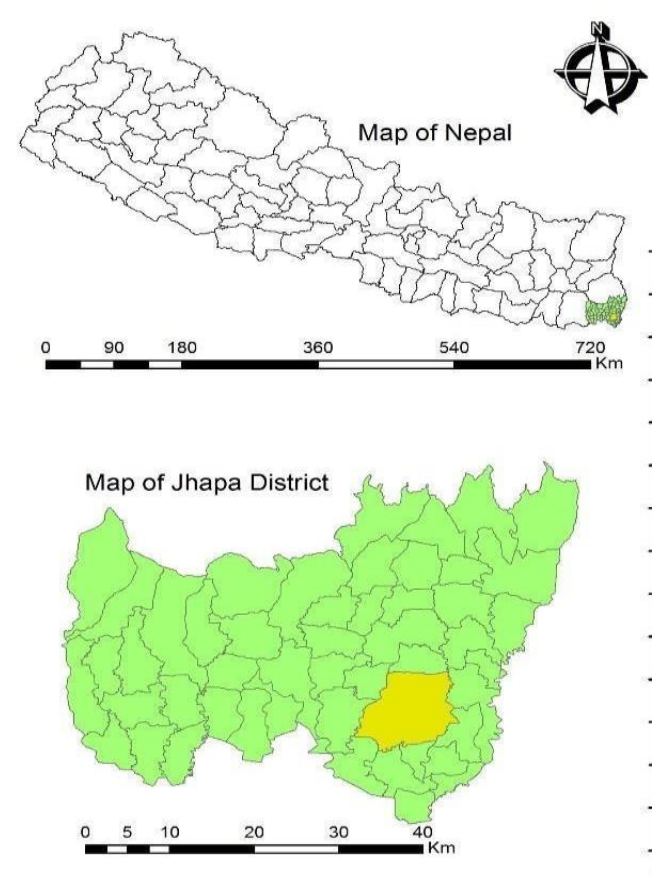




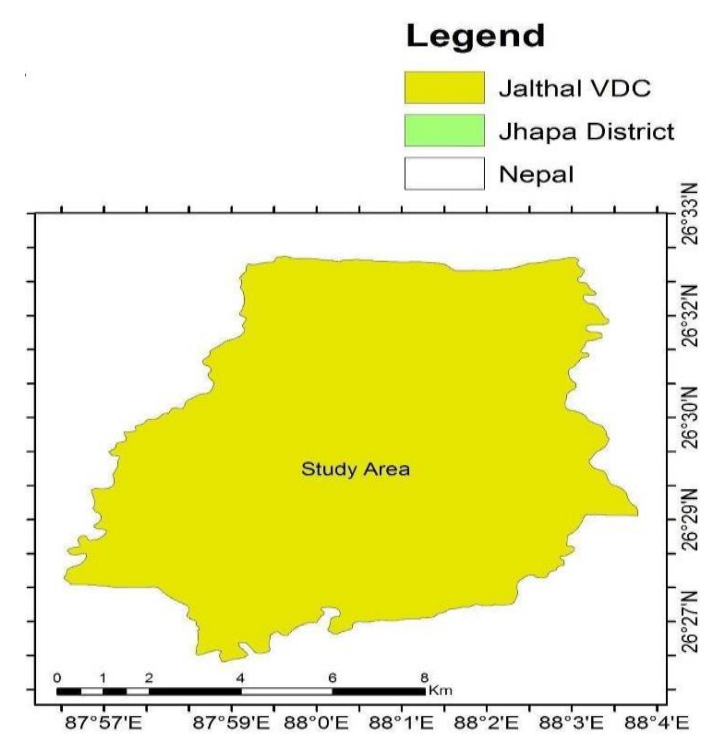

Figure 1: Map of study area.

\section{Fecal sample collection and examination}

Total sample size of the study was 150 , which included the stool samples of Meche people of different age and sex. After proper instructions, vials were given to the people regarding collection of the stool sample, they were given sterile labeled vials and application sticks. A questionnaire pertaining Knowledge Attitude and Practice (KAP) and socioeconomic status of people was done at time of sample collection. The collected stool samples were preserved in potassium dichromate $(2.5 \%)$ solution for further investigation of eggs, larva and adult of intestinal parasites. The microscopic examination was done by unstained preparation of stool smear, stained preparation of stool smear and concentration (Differential flotation technique and Sedimentation technique) methods. All the positive finding was noted. Eggs and cyst were measured by using ocular and stage micrometer. Association of intestinal parasites with age, sex, occupation, drinking water etc. were assessed by using "R", version 3.3.1 software packages.

\section{RESULTS}

\section{Results of stool examination}

Out of 150 sample examined, the general prevalence of the intestinal parasites was found to be 41 (27.33\%) (Fig 2). Specific gastro intestinal parasites identified in the study were namely Ascarislumbricoides (19.33\%), Entamoeba coli (2.67\%), Taeniasolium (2.67\%), Hookworm (2.67\%) and Trichuristrichiura (2\%) (Fig 3). Of total positive samples, protozoan parasite was observed in $9.75 \%$ cases (Fig 4) whereas helminth were observed in $97.56 \%$ cases (Fig 5). A total of 73 samples examined from male and 77 sample from female, $21.91 \%$ and $32.47 \%$ were found to be positive for male and female respectively(fig 6). There was not significant difference in the distribution of parasites between male and female $\left(\chi^{2}=1.6022, \mathrm{df}=1, \mathrm{p}\right.$-value $\left.=0.2056\right)$. Single infection was seen in $92.68 \%$ cases whereas only $7.32 \%$ samples were detected to have double infection (Fig 7). Age wise distribution of parasites in study population was maximum (47.22\%) in age groups $21-40$ and minimum (20.51\%) above 41 years old age group(Table 1).Parasitic infection among age group was found to be statistically significant $\left(\chi^{2}=5.999, \mathrm{df}=2\right.$, pvalue $\left.=0.0498\right)$.

\section{Results of questionnaire survey analysis}

Meche people were interviewed on the basis of the parasitic infection, knowledge of the transmission, control and prevention of the parasites. According to the occupation, prevalence of infection was found to be maximum (32.59\%) among students, minimum among the drivers (20\%) whereas business man and teacher did not show any infection (Fig 8). There was not significant 
difference according to occupation $(\chi 2=4.2039, \quad \mathrm{df}=5, \quad \mathrm{p}$-value=0.519). The prevalence was found higher (30.77\%) among the people who had livestock and domestic animals while $15.15 \%$ was found in peoples who didn't have livestock and domestic animals (Fig 9). No significant difference was observed among infected people on the basis of livestock and domestic animal owner ship $\left(\chi^{2}=2.4235, \mathrm{df}=1\right.$, pvalue $=0.12$ ). It was found that most of the people who believed in traditional method (Dhami, Jhakri) were found to be highly infected (42.31\%) and those consulting with doctors showed minimum infection (12\%) (Fig 10). There was no significant difference in the prevalence of intestinal parasites on the basis of treatment method $\left(\chi^{2}=5.895\right.$, $\mathrm{df}=2$, p-value $=0.0525$ ). The parasitic infection was found to be maximum $(42.86 \%)$ in those who used soil and water as cleaning agent to clean hands and minimum (21.50\%) in those people who used soap and water as cleaning agent (Fig 11). There seems significant difference in the prevalence of the intestinal parasites according to the different agent for cleaning hands $\left(\chi^{2}=6.445, \mathrm{df}=2\right.$, pvalue $=0.0399$ ). Out of 150 people, $70 \%$ were unaware and 30\% were aware about the infection of the parasites. The infection was found higher (30.48\%) among unaware and lower (20\%) among aware people (Table 7). Statistically, distribution of parasites between aware and unaware people was not found significant $\left(\chi^{2}=1.253, \mathrm{df}=1, \mathrm{p}\right.$-value $=$ 0.263). Among 134 non-vegetarian, $28.36 \%$ were infected whereas $18.75 \%$ showed infections among 16 vegetarian (Table 8). The distribution of the parasite between vegetarian and non-vegetarian was not significant $\left(\chi^{2}=0.269, \mathrm{df}=1, \mathrm{p}\right.$-value $\left.=0.604\right)$. The prevalence rate was higher $(85.37 \%)$ among those people who directly drink water without treatment and lower (14\%) in those who drink water after filtration while respondent drinking boiled water didn't have any infections. Significant difference was seen in the distribution of intestinal parasites on the basis of water treatment method $\left(\chi^{2}=14.392, \mathrm{df}=2\right.$, $\mathrm{p}$-value $\left.=0.00075\right)$.

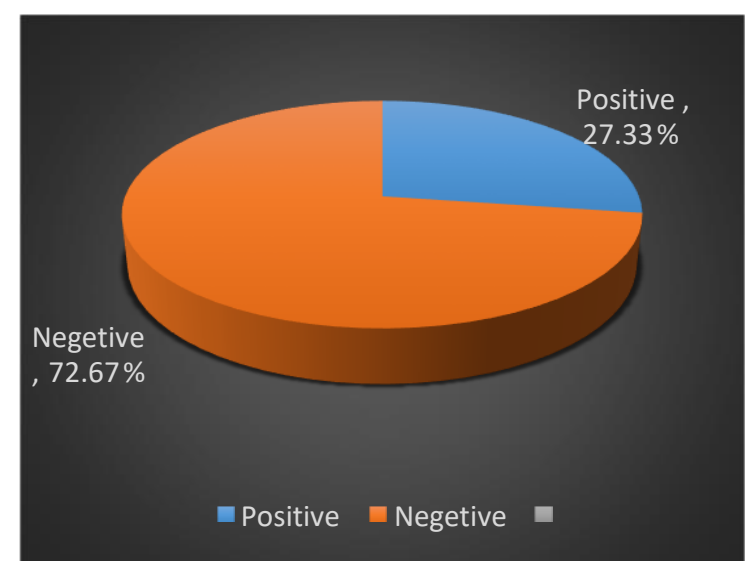

Figure 2:General prevalence of intestinal parasites

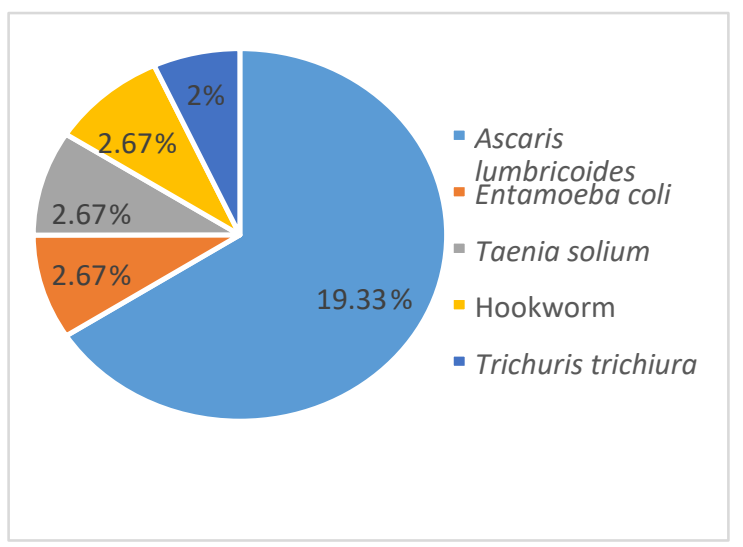

Figure 3: Prevalence specific intestinal parasites

Table 1: Age group-wise Prevalence of Intestinal Parasites

\begin{tabular}{lllll}
\hline S.N. & Age & $\begin{array}{l}\text { Total no. of } \\
\text { samples }\end{array}$ & $\begin{array}{l}\text { +ve } \\
\text { cases }\end{array}$ & +ve \% \\
\hline 1. & $1-20$ & 45 & 16 & 35.56 \\
\hline 2. & $21-40$ & 36 & 17 & 47.22 \\
\hline 3. & $<41$ & 39 & 8 & 20.51 \\
& Total & 150 & 41 & 27.33 \\
& & & & \\
\hline
\end{tabular}




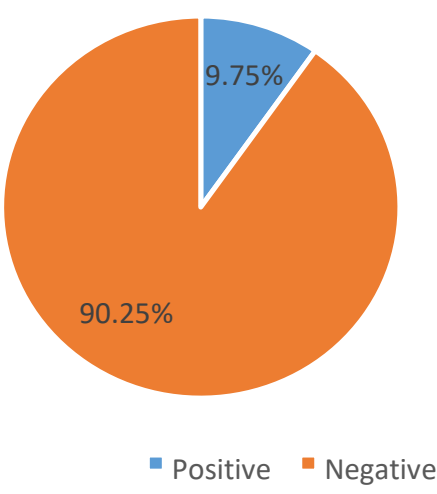

Figure 4: Distribution of protozoan parasite

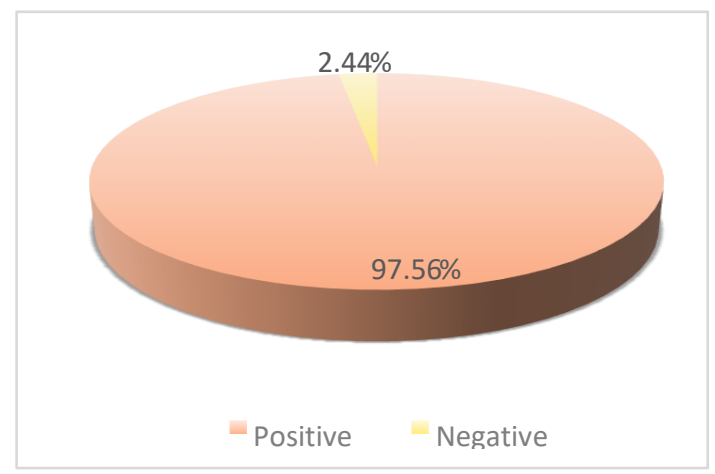

Figure 5: Distribution of helminth parasites

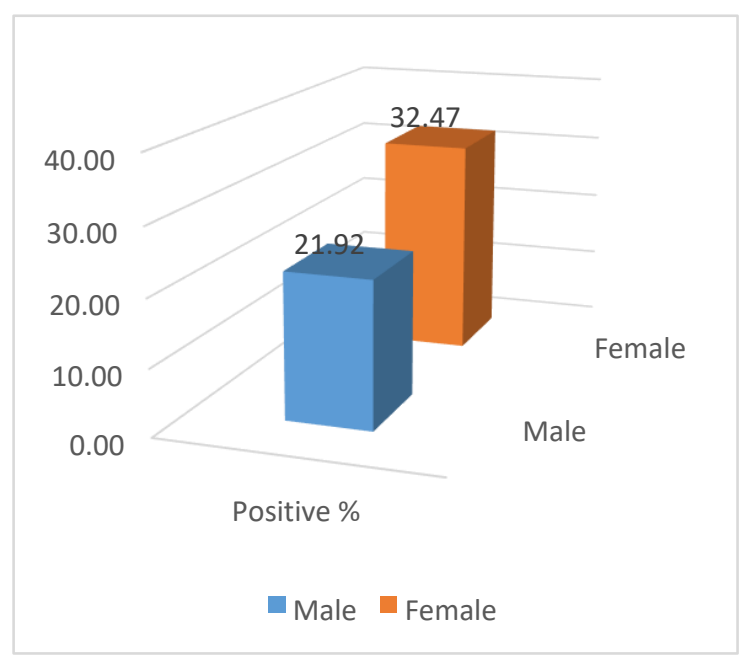

Figure 6: Sex-wise Prevalence of Intestinal Parasites

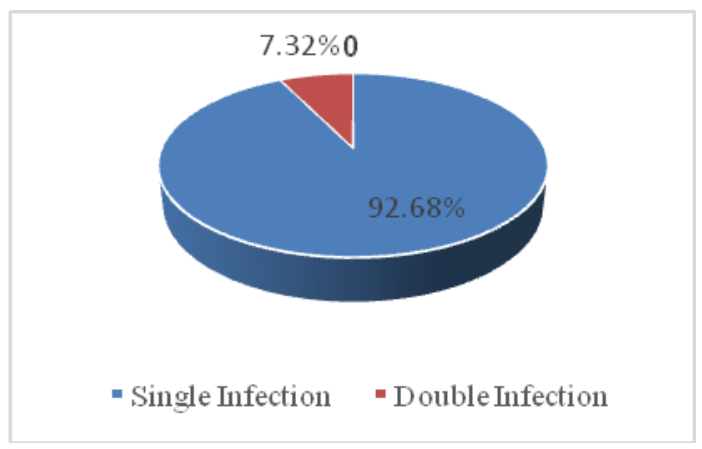

Figure 7: Overall concurrency of intestinal parasites

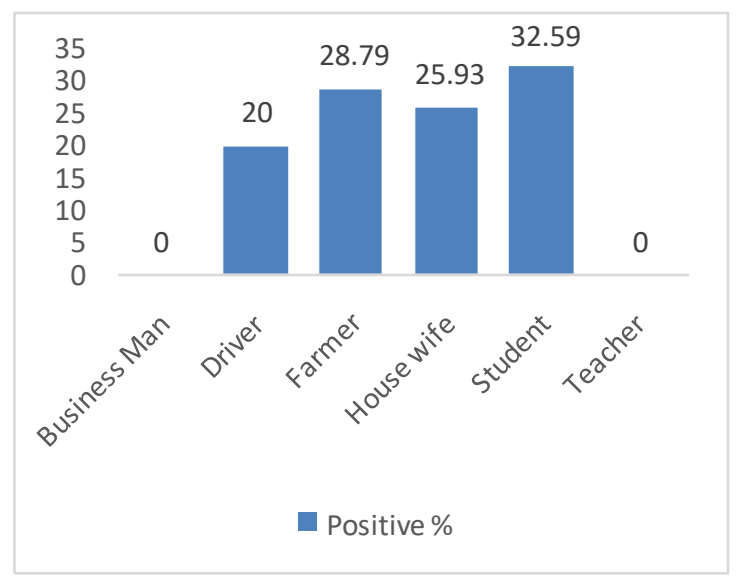

Figure 8: Occupation wise prevalence of intestinal parasites

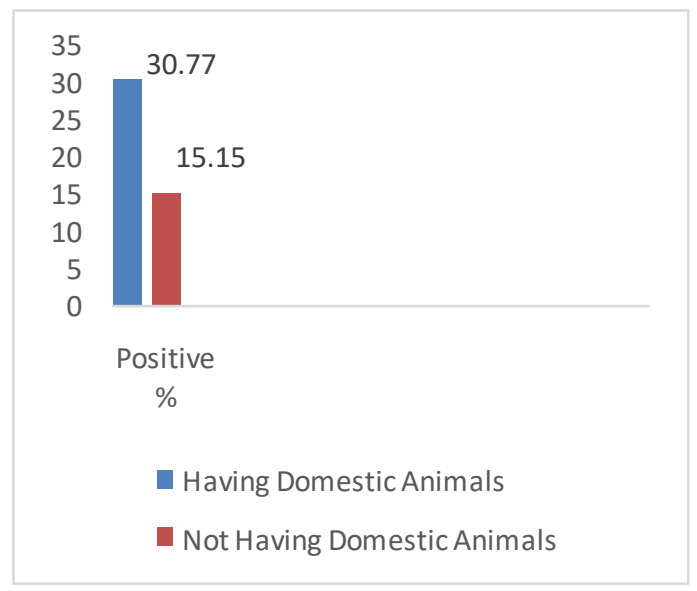

Figure 9: Livestock and Domestic Animals Ownership-wise Prevalence of Intestinal Parasites 


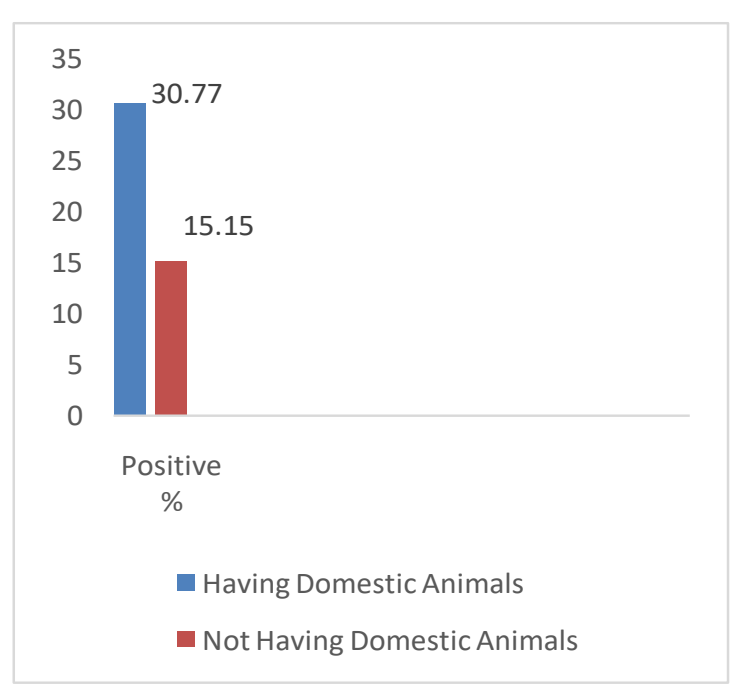

Figure 10: Treatment Method-wise Prevalence of Intestinal Parasites

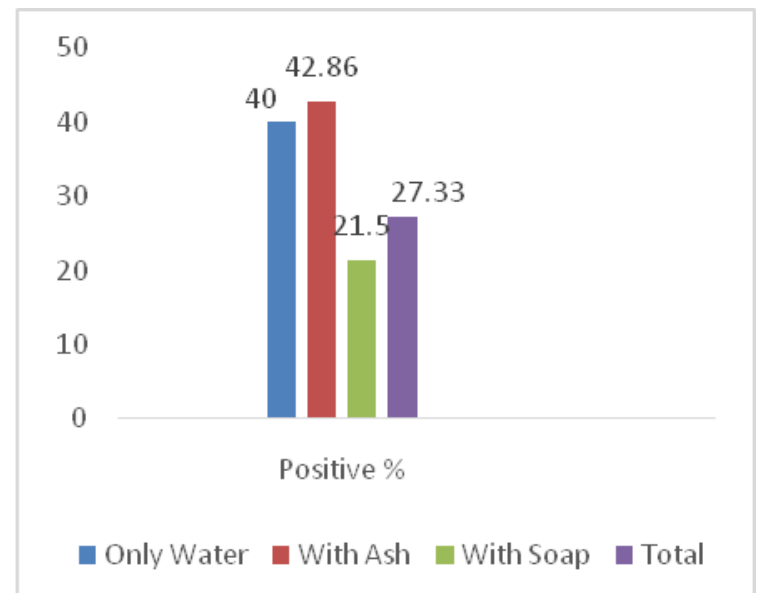

Figure 11: Hand washing wise Prevalence of Intestinal Parasites

Table 2: Knowledge towards intestinal parasites among Meche people

\begin{tabular}{|c|c|c|c|c|c|}
\hline \multirow[t]{2}{*}{ Sex } & \multirow{2}{*}{ 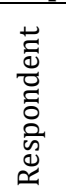 } & \multicolumn{2}{|c|}{ Aware } & \multicolumn{2}{|c|}{ Unaware } \\
\hline & & No. & $\%$ & No. & $\%$ \\
\hline Male & 73 & 22 & 9.1 & 51 & 27.45 \\
\hline Female & 77 & 23 & 30.4 & 54 & 33.33 \\
\hline Total & 150 & 45 & 20 & 105 & 30.48 \\
\hline
\end{tabular}

Table 3: Prevalence of Intestinal Parasites on the basis of Food habit

\begin{tabular}{|c|c|l|c|l|}
\hline \multirow{2}{*}{ Sex } & \multicolumn{2}{|c|}{ Vegetarian } & \multicolumn{2}{c|}{ Non-vegetarian } \\
\cline { 2 - 5 } & No. & $\begin{array}{l}\text { Infected } \\
(\%)\end{array}$ & No. & $\begin{array}{l}\text { Infected } \\
(\%)\end{array}$ \\
\hline Male & 12 & 25.0 & 61 & 21.31 \\
\hline Female & 4 & 0 & 73 & 34.25 \\
\hline Total & 16 & 18.75 & 134 & 28.36 \\
\hline
\end{tabular}

\section{DISCUSSION}

Intestinal parasites are present throughout the world in various degree of prevalence and are the major health problems in areas where there is overcrowding, poor environmental sanitation and personal hygiene practice especially in developing countries [17]. The overall prevalence of intestinal parasites in the present study was found to be $27.33 \%$ which is slightly similar to the results which have also recorded the same prevalence with minor differences [18-26]. In contrast, some studies reported higher prevalence than present study [7, 27-35]. These differences might be due to the place and time differences of the study, health, awareness, education and living standard of people.

The present study recorded higher prevalence as compared with the study of different authors [9, 36-42]. The high prevalence of the intestinal parasites may be attributed to the lack of health education, hand washing behavior, farming profession and non-vegetarian food habit. Most of the vegetable farmer use human excreta as manure which might be the potential source of the infection since farmers go to the farm to tender vegetables.

Among the Meche people the most prevalent intestinal parasite recorded was Ascaris lumbricoides (19.33\%) which is similar to the works which also reported Ascaris 
lumbricoides as most predominant parasites[10, 22, 26-27, 36, 39, 43-49]. This may be due to the water contamination with helminth eggs in the locality, inadequate agent for washing hand after defecation and low economy of poor farmers who usually work bare foot in farm.

The present study revealed more prevalence of the helminths than protozoan parasites. The findings of this study matched with finding which reported helminth parasites as more prevalent than protozoan parasites from Banglore, India[18], Sunsari, Nepal [43], Sarlahi, Nepal [46] and Southern Ehiopia[50]. Other helminthes recorded in present study are Hookworm (2.67\%), Taenia solium (2.67\%) and Trichuris trichiura (2\%). These parasites were also reported from Greek [40] and Abia state, South [51]. This study presents that single infection was found to be maximum (92.68\%) than double (7.32\%) parasitic infection. Similar finding was reported [39, 44, 52]. This might be indication of the condition of insanitary environment, poor living condition, lack of health education associated with poverty, lack of clean water and personal hygiene.

Entamoeba coli was the protozoan parasites recorded in this study which contribute to $2.67 \%$ of total infection, is generally nonpathogenic but sometimes it causes diarrhea and its prevalence could be due to faecal contamination of drinking water which in turn shows poor sanitary practices. Present study is in agreement to the work done from school children of Central Region of Thailand [2], Kathmandu[53] and South Chennai, India [54].

Gender-wise parasitic infection rate was found slightly more common in females $(32.47 \%)$ than in males (21.91\%) which agrees with the findings $[35,48]$. Slightly higher prevalence of parasites in female than in males was reported from, children in Pokhara, elsewhere in Nepal, Chitwan, Nepal[55], Kanti children Hospital Kathmandu [56], Bhusenyi district, Western, Uganda [57] and African urban slum in Nigeria and North-west, Saudi Arabia[58]. The risk factors for high prevalence of parasites among females include lower educational status, their involvement in child care as well as other household works [52] and consuming raw vegetables.

Based on the age of the people included in study, the infection was found higher in the middle age group 21-40 (47.22\%) and lowest among the elder people $(20.51 \%)$ which is slightly similar to the report.[51] The people showing higher prevalence are those involved in farming and house hold activities. On the other hand people of (1-20) years showed high prevalence (35.56\%) compared to elderly people. This age group include school children who are generally highly infected as a result of age and lack acquired immunity $[59,60]$. The present study is different from the reports of studies done among the school going children which showed high prevalence among the school going children under 15 years of age $[38,41,61]$. The finding of the present study showed the higher prevalence (28.36\%) among the non-vegetarian and lower among vegetarian (18.75\%) which is supported by the study of which reported higher prevalence of parasites among nonvegetarian $[21,38,62,63]$. This might be due to consuming infected raw and improperly cooked meat [21]. However the study showed high prevalence among the vegetarian patient of cataract surgery at the eye camps in the rural hilly areas of Nepal [64]. 
In the present study, the infection was found higher (42.86\%) among those people who use soil and water as hand cleaning agent which seems similar to the resultwhere higher prevalence among those using soil/ mud and water as hand cleaning agent was reported[12,22,65]. This study reflects that the highest percentage $(85.37 \%)$ of positive cases of parasitic infection was found in those who used direct tube well water without any treatment which is supported by the finding [65]. This study highlights that prevalence was found maximum (30.77\%) in the people having livestock and domestic mainly pig, duck, cow, goat, hens, which is supported by the results [21,22] who also reported high prevalence in people having livestock and domestic animals. This might be due to the insufficient sanitary conditions, lack of personal hygiene and having nearby livestock and domestic animals.

Most of the respondent (70\%) in this study are unaware about the intestinal parasitic infection among them 30\% were infected by the intestinal parasitic infection whereas of $30 \%$ aware people, 20\% were infected. Most of the people of the Meche community do not have any knowledge of means and modes of the parasitic disease transmission. This finding matched with the results $[22,38,63]$. The present study revealed that most of the people who believe in traditional method such as Dhami, Jhakri, were highly infected (42.31\%) and people consulting doctors show lower prevalence $(12 \%)$ of the parasitic infection which is supported by the results $[21,63]$. It is due to the lack of knowledge, attitude, cultural and behavioral variations.

\section{CONCLUSION}

Overall, the Meche people of the Jalthal VDC of Jhapa district are infected with various kinds of gastrointestinal parasites .Among helminth, Ascarislumbricoideswasmost domionant as compared to others whereas only one protozoan parasite i.e. Entamoeba coli, was detected in this study. The prevalence of intestinal parasites was slightly higher in student. Female revealed higher infections as compared to male. Similarly, unaware respondents are more infected than aware. The people who used soil and water as hand cleaning agent, who drink direct tube well water and who believed in traditional method of treatment showed high infections. It can be concluded that the high prevalence of intestinal parasitic infection in current study is due to the lack of health education program, poverty, lack of awareness, poor environmental sanitation, habit of consuming raw and uncooked food, drinking unsafe water and negligence of school aged students towards their personal hygiene.

\section{ACKNOWLEDGEMENTS}

We would like to express our sincere gratitude to the peoples of Meche community of Jalthal VDC for their co-operation during field work. Similarly, we are grateful to teachers and staffs of Central Department of Zoology for providing necessary equipment to proceed this work. Lastly, I would like to express my heartily thanks to Mr. Roshan poudel and my entire colleague for their support, suggestions and encouragement during research work.

\section{REFERENCE}

1. WHO. 2000. World Health Report Conquering Suffering Enriching Humanity, Health System Improving Performance, WHO, Geneva.

2. Mordi, R.M and Ngwodo, P.O.A. 2007. A study of blood and gastro-intestinal parasites in Edo state. African Journal of Biotech, 6:2201-2207. 
3. Alli, J.A., Kolade, A.F. and Okonko, I.O. 2011. Prevalence of intestinal nematode infection among pregnant women attending antenatal clinic at the University College Hospital, Ibadan, Nigeria. Advances in Applied Science Research, 2:1-13.

4. WHO. 1998. Expert committee report on prevention and control of intestinal parasitic infection. WHO Technical Report Services, 749.

5. Desta, H., Negussie, D. and Eskzyiaw, A. 2014. Prevalence and determinants factors of intestinal parasites among children in Arba Minch town, Southern Ethiopia. American Journal of Health Research, 2(5): 247-256.

6. Rai,S.K., Rai,D.M., Choudhary,D.R. and Sharma, B.K. 2004. Prevalence of intestinal parasitic infestation in school children in the northern eastern part of Kathmandu valley, Nepal. Nepal Medical Collage, Atterkhel, Jorpati, 35 (3):501505.

7. Rai, S.K., Thapa Magar, D., Lekhak, B. and Rai, K.R. 2011. Study of parasitic infection among the children of SukumbasiBasti in Kathmandu valley. Nepal medical College Journal, 13(1): 710.

8. Rai, S.K. and Rai, G. 1999. Ascaris ,ascariasis and its present scenario in Nepal. Journal of Institute of Medicine, 21(1): 1-7.

9. Tandukar, S., Ansari, S., Adhikari, N.B., Shrestha, A., Gautam, J. and Sharma, B. et al., 2013. Intestinal parasitosis in school children of Lalitpur district of Nepal, 6: 449.

10. Estevez, E.G., Levine, J.A. and Warren, J. 1983. Intestinal parasites in a remote Village in Nepal. Journal of Clinical Microbiology17: 160-161.

11. Rai, S.K. and Gurung, C.K. 1986. Intestinal parasitic infection in high school level students of Birgunj city. Journal of Institute of Medicine, 8(1): 33-38.

12. Regmi, P. 2012. Prevalence of Intestinal Parasites and associated risk factors among school children of Kalaiya in Bara District. M.sc. Thesis. Department of Microbiology, Xt. Xavier college, Maitighar Kathmandu, Nepal.

13. Thapa, D., Rai, S.K., Lekhak, B. and Rai, R.R. 2011. Study of parasitic infection among children of SukumbasiBastin Kathmandu Valley. Nepal Medical College, 13(1): 7-10.

14. CBS. 2011. National Population and Housing Report, Vol. 1, Central Bureau of Statistics, Thapathali, Kathmandu, Nepal.

15. NPHC. 2011. National Population and Housing Report, Vol. 6, Central Bureau of Statistics, Thapathali, Kathmandu, Nepal.

16. Rai, S.K. and Dhungana, P. 2002. Value of Plants in Cultural and Ritual Ceremonies of Meche Tribe.
Nepal University Teachers Association, Post Graduate Campus, Biratnagar, Nepal, 5(1): 72-75.

17. WHO. 2010. Mortality and burden of disease. World Health Organization. World Health Statistic, 82-96.

18. Golia, S., Sangeetha, K.T. and Vasudha, C.L. 2014. Prevalence of Parasitic Infections among primary school children in Banglore. International Journal of Basic and Applied Medical Sciences, 4(1): 356-361.

19. Mohammed, AL., Ibrahim, H., Amin, T.T., Aboulmagd, E.,Hablus, H.R. and Zaza, B.O. 2010. Prevalence of intestinal parasitic infection and its relationship with socio-demographics and hygienic habits among male primary school children in Al-Asha, Saudi Arabia. Asian Pacific Journal of Tropical Medicine, 906-912.

20. Mbae, C.K., Nokes, D.J., Mulinge, E., Nyambuna, J., Waruru, A. and Kariuki, S. 2013. Intestinal parasitic infection in children presenting with diarrhea in outpatient and inpatient setting in an informal settlement of Nairobi, Kenya. Biomedical Central, 13: 243.

21. Oli, K.B. 2016. Prevalence of intestinal parasites in Tharu community of Pawanagar VDC of Dang district in relation to their socio-econmic status. M.Sc. Thesis. Central Department of Zoology. Tribhuvan University, Kathmandu, Nepal.

22. Yadav, R.K. 2014. Socio-eonomic status and intestinal parasitosis in Mushar community of Itahari ,Bishnupur VDC of SaptariDstrict. M.Sc. Thesis. Central Department of Zoology, Tribhuvan University, Kathmandu, Nepal.

23. Ammoura, A.M. 2010. The impact of hygienic level on parasite infection to find out the prevalence of intestinal parasites among the primary school children in rural and urban areas in South Jordan. Asian Pacific Journal of Tropical Medicine, 3(2): 148149.

24. Alyousefi, N.A., Mohammed, A.K., Madhy, M. and Lim, A.L. 2011. Association with high prevalence of intestinal protozoan infection among the patients in Sana'a city, Yemen. PLOS one 6(7): 15-19.

25. Tiwari, B.R., Chaudhary, R., Adhikari, N., Jayaswal, S.K., Poudel, T.P. and Rijal, K.R. 2013. Prevalence of Intestinal Parasitic Infections among school children of Dadeldhura District, Nepal. Journal of Health and Science, 3(1): 14-16.

26. Maharjan, M. and Shrestha, R. 2013. Prevalence of intestinal helminth parasites among school children of Bhaktapur district, Nepal. Nepalese Journal of Zoology, 1(1): 48-59.

27. Rai, S.K., Takoo, M., Fazuo, O., Yoko, O., Shoji, U. and Rai, N. et al., 2001. Intestinal parasites in an unknown 
disease outbreak HIT rural hilly area in western Nepal. Nepal Medical Council Journal, 12 (2): 61-64.

28. Shrestha, B. 2001. Intestinal Parasitic Infection in healthy school children of Lalitpur district. Journal of Nepal Medical Association, 41: 266270.

29. Rosino, R.P and D.S. 2009. Socio-economic status of Nepal. Journal of Institute of Medicine, 4(2): 121-123.

30. Florez, O., Bermudez, A., Salcedo, M., Hernandez, L., Araujo, C., Bolanos, M.V. et al. 2012. Intestinal parasitism prevalence amongst children from six indigenous communities residing in Coli, Colombia. Revistadesaludpublica, 14(1): 156-158.

31. Alamir, M., Awoke, W. and Feleke, A. 2013. Intestinal Parasites Infection and associated factors among school children in Dagi Primary School, Amhara National Regional State, Ethiopia, 5(10): 1697-1701.

32. Kirwan, P., Asaolu, O.S., Molly, S.F., Abiona, T.C., Jakson, A.L. and Holland, C.V. 2009. Pattern of soil transmitted helminth infection and impact of four monthly albendazole treatments in pre-school childrenfrom semi-urban communities in Nigeria: A double-blind placebo-controlled randomized trial. Biomedical Centre Infectious Disease, 9(20): 1-13.

33. Jaroli, V.J., Choubisa, S.L., Choubisa, P. and Mogra, N. 2012. Intestinal parasitic infection in Bhil tribe of Rajsthan, India. Indian Society of Parasitology, 36(2):143-148.

34. Al-Mekhlafi, A.M., Ghani, R.A., al-Eryani, S.M., Saif-ali, R. and Madhy, A.K. 2016. Scholl based prevalence of intestinal parasitic infection and associated risk factors in rural communities of Sana'a, Yemen. Acta Tropical, 163: 135-141.

35. Bhandari, N., Kausaph, V. and Neupane, GP. 2011. Intestinal parasitic infection among school age children. Journal of Nepal Health Research Council, 9(18): 30-32.

36. Tandukar, S., Sherchand, B., Thapa, P., Malla, D, Bhandari, D., Ghaju, R. et al. 2015. Intestinal parasitic infection among school going children in Kathmandu valley. Austin Journal of Pediatrics, 2(2): 1-4.

37. Jaiswal , S., Panta , D.R., Tiwari,B.R., Sah, J.P., Bhandari, R. and Upadhyaya, S. 2014. Prevalence of the intestinal parasites among the school children of Bharatpokhari VDC Kaski, Nepal. British Microbiological Research Journal, 4(9): 1007-1012.

38. Pandey, S., Lama, A. and Shrestha, R.B. 2015. Intestinal parasitic infections among school children of Northern Kathmandu, Nepal. Asian Pacific Journal of Tropical Disease, 5(1): 89-92.

39. Khanal. L.K., Rai, S.K., Khanal., R.P. and Ghimire ,G. 2011. Status of intestinal parasitosis among hospital visiting patient in Deukhuryvalley,Dang, Nepal. Nepal Medical College, 13(2): 100-102.
40. Frydas, S.E., Siochu, A.E., Constantinidis, T.C., Mavrovouniotis, Ch., Papazahariadou, M.G., Papadopoulas, E.G. et al. 2004. Prevalence of gastrointestinal parasites in the Greek population: local people and refugees. Annals of Gastroenterology, 17(2): 194-198.

41. Rayapu, V., Dhandapany, S.P., Sheker, I.A. and Kasukurthy, S. 2014. Prevalence of intestinal Helminthic parasites in school going children in rural area of Kuppam, Andhra Pradesh. International Journal of Basic Medical Sciences and Pharmacy (IJBMSP), 2(2): 76-79.

42. Chakma, T., Rao, P.V. and Tiwary, R.S. 2000. Prevalence of anemia and infection in tribal areas of Madhya Pradesh. Journal of Medical Association, 98(9): 567570.

43. Chongbang, R., Dangol, P., Chakraworti, A. and Khanal, H. 2016. Parasitic infection among children of Squatter community in Dharan municipality, sunsari, Nepal. International Journal of Applied Science and Biotechnology, 4(2): 203-206.

44. Abera, A. and Nibert, E. 2014. Prevalence of gastrointestinal helminth infection and associated risk factor among school children in Tilli town, Northwest, Ethiopia. Asian Pacific Journal of Tropical Medicine, 4 (2): 525-530.

45. Agrawal, P.K., Rai, S.K., Khanal, L.K., Ghimire, G., Banjara, M.R. and Singh, A. 2012. Intestinal Parasitic Infections among Patients Attending Nepal Medical College Teaching Hospital, Kathmandu, Nepal. Nepal Medical College Journal, 14(2): 80-83.

46. Malla, B., Sherchand, J.B., Ghimire, P., BC, R.K. and Gauchan, P. 2004. Prevalence of intestinal parasitic infection and malnutrition among children in rural community Sarlahi, Nepal. Journal of the Nepal Health and Research Council, 2(1):1-4.

47. Agrawal, P.K., Rai, S.K., Khanal, L.K., Ghimire, G., Banjara, M.R. and Singh, A. 2014. Intestinal Parasitic Infections among patients attending Nepal Medical College Teaching Hospital, Kathmandu, Nepal. Nepal Medical College Journal, 14(2): 80-83.

48. Khadka, K.S., Kaphle, H.P., Gurung, K., Shah, Y. and Sigdel, M. 2013. Study of Intestinal Parasitosis among school going children in Pokhara, Nepal. Journal of Health and Science, 3(1): 47-50.

49. Singh, G.K., Parajuli, K.P., Shrestha, M., Pandey, S. and Yadav, S.C. 2014. Journal of Nobel Medical College, 2(1): 13-17.

50. Abossie, A. and Mohammed, S. 2014. Assement of prevalence of intestinal parasitosis and associated risk factors among primary school children in Chencha town, South Ethiopia. Biomedical Central Public Health, 14(166): 1-8. 
51. Nduka, F.O., Nwaugo, V.O. and Nwachakwu, N.C. 2006. Human intestinal parasite infection in Shiagu, A lead mining area of Abia state. Animal Research International, 3(3): 505-507.

52. Shrestha, A., K.C., N. and Sharma, R. 2012. Prevalence of Intestinal Parasitosis among School Children in Baglung District of Western Nepal. Kathmandu University MedicalJournal, 37(1): 3-6.

53. Mukhiya , R.K., Rai, S.K., Karki, A.B. and Prajapati, A. 2012. Intestinal protozoan parasitic infection among school children. Journal of Health Research Council, 10(22): 204- 207.

54. Dhanabal, J., Selvadoss, P.P. and Muthuswamy, K. 2014. Comparative study of prevalence of intestinal parasites in lowsocioeconomic areas from south Chennai. Journal of Parasitology Research, 1-7.

55. Bhattachan, B., Panta, Y.B., Tiwari, S., Thapa Magar, D., Sherchand, J.B., Rai, G. et al 2015. Intestinal parasitic infection among school children in Chitwan district of Nepal. Journal of Nepal Health Research Council, 37(2): 79-84.

56. Uga, S., Rai, S.K. and Kimura, K. 2004. Parasites detected from diarrheal stool sample collected in Kathmandu Nepal. Southeast Asian journal of Tropical Medical Public Health, 35: 19-23.

57. Ntulume, I., Tibyangye, J., Alievo, A.A. and Banson, B.J. 2017. Prevalence of intestinal protozoan infection and the associated risk factors among children in Bushenyi, district, Western, Uganda. International Journal of Tropical Disease and Health, 23(2): 1-9.

58. Amer, O.H., Ibraheem, M.A. and Haouas, N.S. 2015. Prevalence of intestinal parasitic infection among patient in local public hospital of Hail, North Western, Saudi Arabia. Asian Pacific Journal of Tropical Medicine, 9(1): 44.

59. Mbanugo, J. I. and Onyebuchi, C. J. 2002. Prevalence of Intestinal Parasites in Ezinifite Community in Aguata LGA of Anambra State. Nigerian Journal of Parasitology, 23: 27-34.

60. Adeyeba, 0. A. and Akinlabi, A. M. 2002. Intestinal Parasitic infections among school children in rural community, South Nigerian. Nigerian Journal of Parasitology, 23: 11 - 18.

61. Ojurongbe, O., Oyesiji, K.F., Oja, J.A., Odefioye, O.A., Olowe, A.O. and Opaleye, 0.O. et al. 2014. Soil transmitted helminth infections among primary school children in Lle-lfe Southwest, Nigeria: A crosssectional study. International Research Journal of Medicine and Medical Sciences, 2(1): 6-10.

62. Ara, S. 2014. Prevalence of intestinal parasitic infection among Muslim population of Chorni VDC, Parsa, Nepal. M.Sc. Thesis. Central Department of Zoology. Tribhuvan University, Kathmandu, Nepal.
63. Sah, A.K. 2012. Prevalence of intestinal parasites among Tharu community of Rajhena VDC of Banke district. M.sc. Thesis. Central Department of Zoology. Tribhuvan University, Kathmandu, Nepal.

64. Rai, S.K., Gurung, S., Saiiju, R., Bajracharya, L., Rai, N., Gurung, K. et al 2008. Intestinal parasitosis among subjects undergoing cataract surgery at the eye camps in rural hilly areas of Nepal. Nepal Medical College Journal, 10(2): 100-103.

\section{Corresponding Author: Janak Subedi \\ Lecturer \\ Central Department of Zoology \\ Tribhuwan University \\ Kirtiput, Kathmandu, Nepal}

